\title{
Challenges During Transition from Traditional Class Room Teaching to Online Teaching in Covid-19 Lockdown
}

\author{
Mr. Santhosh Chandu Pawar ${ }^{1}$ \\ Assistant Professor, Department of Computer Science, College of Agriculture, Kalaburagi, India ${ }^{1}$
}

\begin{abstract}
During the Covid-19 Pandemic suddenly lockdown is imposed on the entire country ,except essential and emergency services all other services and activities are suspended, due to fast spreading of Corona virus and to maintain the social distancing among the people, students and teachers all the educational activities like Class room teaching, all the Schools, Colleges and University examinations are suspended including laboratory work ,Physical movements are stopped. As the traditional class room teaching activities are suspended and encouraged to Online teaching learning methods, Transitioning from face-to-face training to online teaching requires rethinking and recalibrating of course materials and also essentially forced to develop a required Skill to Online Teaching learning activities among teachers and students. Due to the nature of the online environment, lectures, exercises, and assessments that have worked in a faceto-face class need to be little modified or replaced. A classroom course is defined as a traditional non-native teaching style in which students sit in a room and face-to-face with a teacher. Online courses are defined as courses offered through a web-based learning platform using interactive learning strategies through internet. The transition from traditional Class room to Online class is a challenging task for teachers and students and also for educational institutes.
\end{abstract}

Keywords: Online teaching, transition, student, teacher, traditional teaching, educational institutes, Online meeting.

\section{INTRODUCTION}

Technology has been a growing trend for higher education and personalized learning, the online Classes or online meeting helped the students to keep updated with their course and also be in touch with their respective course teacher and teaching learning activities of college. Now a day online class and online meeting are the essential part of most of the educational institutes. The Transition of from traditional class room teaching to the online teaching is an essential in these days and while this transition phase Institutes, students and teacher have faced many challenges. A Classroom teaching is defined as the traditional non-native teaching style in which students sit in a room and listen to a teacher, with face-to-face interactions. An online course is defined as one that is taken through a Web-based learning platform using interactive teaching strategies. This transition from traditional learning to online learning can be challenging for schools and teachers. In addition, the education community may ask many questions about how and what can be done to continue and improve student education experiences during this transitional phase.

Comparing face-to-face and online learning, online lack of human interaction, lack of opportunities for collaborative learning, supervision of teachers, and, most seriously, lack of hands-on learning opportunities in complex subjects A large learning gap is revealed. Science and Maths. In addition, institutes address the challenges of quality online learning and use technology to provide students with a rich and immersive holistic learning experience. The education has been transformed online and now includes ICT components that help overcome all the challenges posed by the physical distance between teachers and students. In addition to helping users overcome these challenges, ICT has the potential and ability to bring unexpected improvements to the classroom, improve student and teacher performance, and lead to a better learning experience. Here are some integrated ICT-based teaching and learning strategies that can "improve" the quality of online classrooms.

Technology enables teachers to meet most of these online classroom needs. Technology is a great tool because it can be used to tailor learning to suit a student's level, interests, academic and social needs. Rich text, images, videos, sounds and games are fun, exciting, supportive and hard to learn. As digital natives, students view online classes as learning, are constantly setting new learning goals. Students can also learn at their own pace and take as many lessons as possible before moving on to the next stage. Traditional classes are taught by teachers, who make all decisions about what, when, how and to what extent the teacher does. In online classrooms, teachers can motivate, interest, and engage their students by allowing them to choose a "learning method". The selection of events varies from audio/video podcasts, presentations, research, research projects, and quizzes, through games, reports with illustrations and graphics, news reports and many more activities [9]. 
International Journal of Innovative Research in Electrical, Electronics, Instrumentation and Control Engineering

Vol. 8, Issue 8, August 2020

DOI 10.17148/IJIREEICE.2020.8803

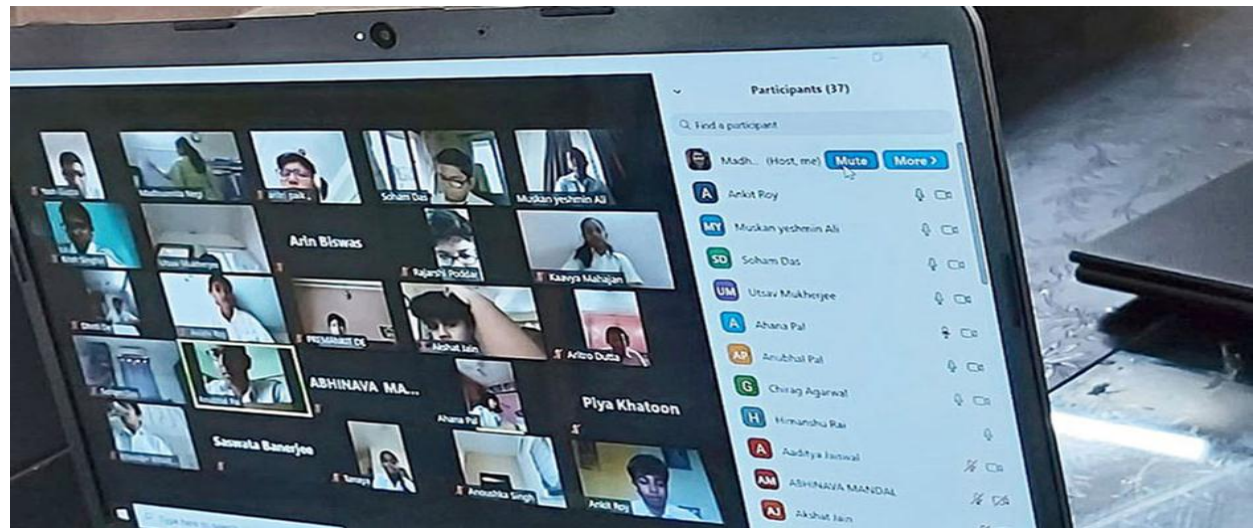

Fig-1: Live Online Class[7]

The only hope they have is internet access so that students do not miss regular classes without affecting the learning process. Therefore, the primary responsibility for implementing this initiative and the transition regime lies with the school administrator and teachers. Will moving from offline to online impact education? Industry experts argue that moving to online learning is not an easy task, but agree that there may be ways to overcome these challenges. Schools should have a positive impact on students, rather than stop learning because of this outbreak. Teachers around the world are working on the transition to online learning [4].

\section{CHALLENGES FACED DURING TRANSITION FROM TRADITIONAL CLASS ROOM TEACHING TO ONLINE TEACHING}

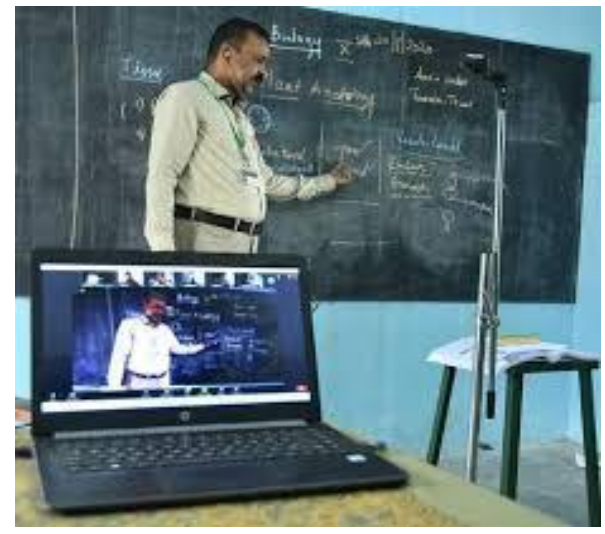

Fig-2: Teacher taking Online in College [8]

Challenges faced by institutes:

- Facilitating the ICT infrastructure to conduct the Online Classes.

- Providing training for teachers to Conduct Online Classes.

- Providing High speed internet facilities.

- Network management at college level.

Challenges faced by teachers:

- Lack of skill in using the Online teaching platform and methodologies.

- Modification in teaching plan and methodologies.

- Internet Network issues

- Low internet speed.

- $\quad$ Sometime difficult to convince students during online Class.

Challenges faced by the Student during Online Classes:

- Many students are not having Smart Phones, Laptop, Computers or ICT Devices with them to attend online Class.

- Scarcity of internet Data.

- Low internet Speed. 
International Journal of Innovative Research in

Electrical, Electronics, Instrumentation and Control Engineering

Vol. 8, Issue 8, August 2020

\section{DOI 10.17148/IJIREEICE.2020.8803}

- Mobile Network problem in their region.

- Lack of skill how to operate online tools and platforms.

- Many Students are not having proper Class Environment in their home to attend online Classes.

- Some time Students are unable Concentrate on Class because mobile is also entertainment device.

Challenges faced by the Parents during Online Classes:

- Expenditure to Purchase the new mobile phones or laptops for their children's

- Creating Class room environment in home.

- Worrying about whether Children's are understanding to online class or not.

- Motivate children to study properly during lockdown.

Other Common problems and Solutions of learners:

- Learners can have inappropriate expectations: articulate expectations, policies and routines.

- Learners may feel isolated and disconnected: small group discussions or synchronized business hours in a face-toface format.

- Learners should be actively involved: discussion [6].

\section{BENEFITS OF ONLINE TEACHING}

- Students can use the lecture content at their own pace, rewinding and re-watching the video as needed to understand the material.

- Students can work alongside web-based tools that encourage collaboration \& provide feedback when it is most useful.

- Students spend time discussing and applying course content. This allows you to learn more about the course content and keep it longer.

- Students can schedule their study time in a busy schedule to better balance work and family responsibilities.

- Shy students may find it easier to participate in forums and chat rooms than to discuss them in person [2].

Online education is an integral part of the nursing education program. Taking responsibility for designing and delivering asynchronous online courses can be challenging, especially for aspiring teachers. The evidence-based aspects of designing, delivering and evaluating online courses are also challenging for educators. Education is a process that encourages learning, knowledge, skills, values, beliefs and habits. Teaching methods include teaching, learning, storytelling, discussion, and direct research. Instructors are often led by instructors, but students can also practice independently. Education can take place in a formal or informal setting, and any experience that has a formative influence on the way a person thinks, feels or behaves is considered educational. The teaching method is called pedagogy.

\section{CONCLUSION}

During lockdown all the nonessential activities are stopped and traditional classroom teaching activities are suspended which encouraged for Online teaching mode, during this transition from traditional to online teaching many challenges are faced by teachers, students and teaching institutes and these challenges are effectively addressed by collective working of teachers and students with the support of institutes and effective Govt Policies, Traditional methods are being replaced by modern teaching methods, and audio-visual effects are a major trend that has changed the overall scenario, Like most aspects of teaching, running an effective online class is an art. It will take time to develop the pedagogical approach that works for you, so be patient with yourself, careful planning will ease this change and ensure success in online class.

\section{REFERENCES}

[1]. https://cpb-us-w2.wpmucdn.com/u.osu.edu/dist/a/11084/files/2015/05/Transition-from-Classroom-to-Online-Teaching-2c36jq3.pdf.

[2]. https://ctl.wiley.com/transitioning-to-an-online-class/

[3]. https://www.readinghalloffame.org/sites/default/files/transformation_of_traditional_face-to-face_teaching_to_mobile_teaching_and_learning_ pedagogical_per.pdf

[4]. https://www.embibe.com/exams/tips-for-transition-to-online-teaching/

[5]. https://www.game-learn.com/8-problems-of-online-training-and-how-to-solve-them/

[6]. https://go.marybaldwin.edu/education/2018/02/23/teaching-online-challenges-solutions/

[7]. https://www.google.com/search?q=online+class\&source=lnms\&tbm=isch\&sa=X\&ved=2ahUKEwiw7bLvsrTrAhVJ6nMBHf9RAikQ_AUoAX oECA8QAw\&biw=1349\&bih=558\#imgrc=vqwwT7-D3WPtAM

[8]. https://www.google.com/search?q=online\%20class\&tbm=isch\&tbs=rimg\%3ACb6sME-_1g91jYU9vfqaL_1g\&hl=en\&sa=X\&ved=0CAIQrnZqFwoTCMDS9YmztOsCFQAAAAAdAAAAABAI $\&$ biw $=1332 \&$ bih $=558$

[9]. https://timesofindia.indiatimes.com/blogs/edutrends-india/challenges-of-quality-in-online-learning/ 
International Journal of Innovative Research in Electrical, Electronics, Instrumentation and Control Engineering

Vol. 8, Issue 8, August 2020

DOI 10.17148/IJIREEICE.2020.8803 